\title{
Sraffa, Marshall and the principle of continuity
}

\author{
Nuno Ornelas Martins*
}

\begin{abstract}
This article addresses Piero Sraffa's critique of Alfred Marshall's supply-anddemand framework, and Sraffa's later book Production of Commodities, taking into account an aspect that has been relatively neglected in the literature, namely the ontology underlying the conceptions of Sraffa and Marshall. This ontological dimension can be best understood through Sraffa's critique of the principle of continuity. The principle of continuity was used by Marshall as a methodological justification for the use of partial equilibrium methods in the analysis of supply and demand, in a context where different causes are deeply interconnected. Sraffa acknowledges the existence of interconnectedness, but rejects Marshall's methodology, which is based on the principle of continuity, as it becomes clear in his unpublished manuscripts, which are examined here.
\end{abstract}

Key words: Ontology, Continuity, Objectivism, Classical political economy FEL classifications: B24, B41

\section{Introduction}

The published writings of the Cambridge Italian economist Piero Sraffa have generated much controversy throughout the history of economic thought. There are two fundamental moments in the published writings of Sraffa. The first moment is Sraffa's $(1925,1926)$ critique of Alfred Marshall's neoclassical framework, and of the use of partial equilibrium analysis and its geometrical representation through supply-anddemand diagrams. In the late 1920s, Sraffa came to interpret the classical political economists in a new light, which led to a long period until the second fundamental moment, when Sraffa finally published Production of Commodities by Means of Commodities, in 1960. Heroismo, Portugal; email: nmartins@uac.pt

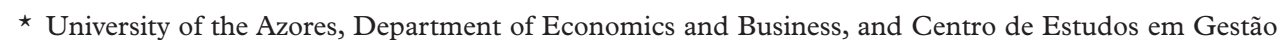
e Economia. The author is most grateful to Pierangelo Garegnani, literary executor of Piero Sraffa's papers and correspondence, for permission to quote from Sraffa unpublished papers, and to Jonathan Smith, for his help when going through the unpublished papers of Piero Sraffa and Henry Sidgwick.

1 The references to the unpublished writings of Henry Sidgwick and Piero Sraffa are those in the catalogue prepared by Jonathan Smith, Archivist at the Wren Library, Trinity College, Cambridge. Sraffa used both round and square brackets; thus, all additions will be bracketed by \{and in order to avoid confusion.

(C) The Author 2013. Published by Oxford University Press on behalf of the Cambridge Political Economy Society. All rights reserved. 


\section{Page 2 of 20 N. O. Martins}

Heinz Kurz and Neri Salvadori (2005) suggest that this change of Sraffa's interpretation of the classical authors was gradual, resulting from a reading of Marx in 1927 and 1928. Pierangelo Garegnani (2005, p. 488), in contrast, argues that the change 'does not appear to have been gradual, but to have rather been a matter of months, if not weeks, early in the Autumn of 1927'. During this period, Sraffa developed the equations that would ultimately lead to his 1960 book and subsequently read (or reread) Marx in light of his new discovery. As Garegnani (2005) convincingly argues, this discovery created a difficulty for Sraffa, who had agreed to lecture in Cambridge in October 1927 on the theory of value, a subject on which Sraffa was rapidly changing his mind towards a new interpretation following his discovery.

In the new interpretation Sraffa reaches after 1927, there is a clear distinction between two theories of value, which answer different types of questions. The differences between these two theories had been overlooked by Marshall (1920), who developed the supply-and-demand framework attempting also to make it compatible with the classical political economy of Smith and Ricardo, in what was termed neoclassical economics by Thorstein Veblen (1900), a perspective that would supposedly reconcile the new elements of marginalism with classical political economy.

For Marshall, the two theories of value, which Sraffa came to find irreconcilable and concerned with different questions, would be compatible. Following Marshall, there is a tendency to interpret classical political economy as an early form of neoclassical economics, i.e. as an endeavour that already presupposes a supply-and-demand framework. Thus, Marshall (1920) argues that there is continuity in the history of economic thought, going through Smith, Ricardo and Mill to Marshall's own contribution.

Note that Sraffa (D3/12/11/11) uses the term 'principle of continuity' to apply to time, to distinguish 'long and short periods', and as applied to matter and the 'consideration of the margins as infinitesimals'. Marshall, in contrast, uses the term 'continuity' to denote continuity in the history of economic thought. The expression 'principle of continuity' is used in this article in Sraffa's sense, and not to denote continuity in the history of economic thought, which Marshall believes to exist between his work and that of the classicals.

While authors such as Jean-Baptiste Say, Thomas Robert Malthus and, later, John Stuart Mill may be seen as portraying an embryonic form of supply-and-demand analysis, the same cannot be said of Smith, Ricardo and Marx, according to Sraffa's perspective of their standpoint. Sraffa interprets the perspective of Smith, Ricardo and Marx as one where the natural price (or price of production, to use Marx's terminology) can be found by studying the conditions of production without looking at demand.

A central question in this context concerns how the conditions of production determine the natural price (or price of production), which would then be the cornerstone of the classical perspective of Smith, Ricardo and Marx. Sraffa's (1960) contribution can be seen as an attempt to achieve a satisfactory answer to this question, i.e. a theory of the way in which prices are determined by the process of production. In so doing, Sraffa is interpreting Smith, Ricardo, Marx and the classical political economists since Petty as being engaged in a very different project from Marshall's supply-and-demand framework.

A crucial element, which ultimately led Sraffa to develop an alternative framework, is the principle of continuity, which is grounded on Marshall's interpretation of the differential calculus of Isaac Newton and its notion of continuous time, which is essential to Marshall's partial equilibrium analysis and to the use of supply-and-demand curves 
in Marshallian economics. The role of the principle of continuity in Sraffa's critique has been relatively neglected in the literature or, at best, touched upon only brieflye.g. by Kurz and Salvadori (2005, p. 85).

In the present article, Sraffa's critique of Marshallian neoclassical economics and the interpretation of classical political economy Sraffa developed after 1927 will be assessed, taking into account Sraffa's approach to the principle of continuity and to the notion of continuous time while drawing upon Sraffa's unpublished papers at the Wren Library, Trinity College, Cambridge.

\section{Natural prices, demand and supply}

According to the view Sraffa developed after 1927, there are two fundamental theories of value, which answer different types of questions. For one of them, which became more prominent with authors like William Petty, Adam Smith and David Ricardo, there is an objective conception of value, where value depends upon the conditions of production that will determine the natural price. This is the framework that underlies classical political economy. Writing within this tradition, Smith defines effectual demand as the demand of those who are willing to pay the natural price; thus, effectual demand is not an independent concept from the natural price, for it is defined in terms of the natural price. That is, there is a sequential explanation of value, where conditions of production determine the natural price, which in turn is a necessary element to define effectual demand. Sraffa's (1960) contribution can be seen as a revival of this perspective, i.e. of classical political economy, as Ronald Meek (1961) argued.

For another perspective of value (which underpins neoclassical economics and became the dominant perspective after the marginalist revolution), prices are not explained in a sequential way (where the conditions of production determine natural prices and the latter are in turn a necessary element to define effectual demand, as in classical political economy). Rather, prices and quantities are determined mutually, by supply and demand, which are mutually independent factors. Thus, instead of having natural prices as an element used to define effectual demand, demand is seen as an independent factor which, with supply, determines prices (and quantities).

The latter perspective, of mutual determination of prices and quantities, was developed and systematised by Alfred Marshall, who criticises William Stanley Jevons for adopting a sequential explanation of value. According to Marshall, Jevons resorts to a sequential framework where the cost of production determines supply, supply determines marginal utility (which Jevons, 1871, calls the 'final degree of utility') and marginal utility determines value. Commenting on Jevons' perspective, Marshall writes:

the greatest objection of all to his formal statement of his central doctrine is that it does not represent supply price, demand price and amount produced as mutually determining one another (subject to certain other conditions), but as determined one by another in a series. It is as though when three balls $A, B$, and $C$ rest against one another in a bowl, instead of saying that the position of the three mutually determines one another under the action of gravity, he had said that $A$ determines $B$, and $B$ determines $C$. Someone else however with equal justice might say that $C$ determines $B$ and $B$ determines $A$. (Marshall, 1920, p. 674)

This statement could also be aimed at the sequential interpretation of classical political economy, where costs of production determine value (or natural prices) and the latter are a determinant of demand. But Marshall notes that Ricardo did not have 


\section{Page 4 of $20 \quad$ N. O. Martins}

the technical resources available to Jevons, which would enable a conceptualisation in terms of a mutual determination of prices and quantities, the one Marshall develops.

Also, Marshall believed that he developed his approach independently of Jevons. In Marshall's early theory of value, demand (and supply) schedules are defined by looking at how much each different individual is willing to pay (or to receive) for a given good; thus, we do not have a final (or marginal) degree of utility of a single individual (as for Jevons), but rather a 'marginal agent'. Just like Smith when defining effectual demand, the early Marshall reasons not in terms of variations within the mind of a single individual, but in terms of variations between the prices different individuals are willing to pay.

In the Principles of Economics we already find Marshall (1920, p. 79) writing about the consumer at the 'margin of doubt', where the decision to buy depends on 'the marginal utility of the thing to him'. But this comes after Marshall's (1920, p. 77) remark that 'much that is of chief interest in the science of wants, is borrowed from the science of efforts and activities', and therefore the study of psychological phenomena is subsidiary to a more general study of human activity. Thus, Gerald Shove (1942, p. 307) writes that 'Marshall began with the objective demand and supply schedules, the phenomena of the market place, and worked backwards from them to their psychological basis, not (as was the case with Jevons) the other way about'- -see also Simon Cook (2009, pp. 178-9), who discusses this issue with reference to Marshall's early essay 'On Value' and also refers to Shove's quote.

Marshall's perspective was thus not a simple reconciliation between classical political economy (as systematised by Ricardo) and marginalism (as advanced by Jevons and others). Marshall was critical of Jevons' sequential method and developed his own ideas on marginalism independently. Furthermore, as Shove notes, Marshall wrote, in a letter to J. B. Clark dated 24 March 1908:

One thing alone in American criticism irritates me, though it need not be unkindly meant. It is the suggestion that I try to 'compromise between' or 'reconcile' divergent schools of thought. (Marshall, as cited in Shove, 1942, p. 295)

And a reason why Marshall saw his contribution as a novel advance, rather than a reconciliation of what was done by others, lies in the fact that while others proposed a sequential determination of value, Marshall advanced a method of mutual determination of value.

This emphasis on mutual determination can be seen in light of Marshall's philosophical perspective, where reality is seen as an interconnected whole. In fact, Marshall's early philosophical perspective was strongly influenced by Friedrich Hegel, for whom all reality is a deeply interconnected whole, as Cook (2009) explains.

Peter Groenewegen (2011), criticising Cook's (2009) position, argues that Marshall's reading of Hegel was limited, because 'Marshall ignored work by Hegel other than his Philosophy of History' and 'Marshall's use of Hegel illustrates the manner in which he often used texts, altering their meaning to make them conform more to what he himself wanted to believe on the issue in question', and lastly because 'although specific use of Hegel by Marshall featured especially in work from the second half of the 1870s, and some of it occurred in the Principles of Economics, the influence of Hegel was somewhat loose and invariably minor' (Groenewegen, 2011, p. 138).

Nevertheless, whatever is the case concerning Marshall's Hegelianism, there is one aspect often identified with Hegelianism that was certainly central for Marshall. This 
is the idea that the whole is more than the sum of the parts. Bertrand Russell (1945) acknowledges this as a central (or maybe the central) aspect of Hegel's philosophy, in order to then criticise this position, which was then gaining ground at Cambridge (at the time under the name of 'internal relation', i.e. a relation that is constitutive of the related entities, making the whole more than the sum of their parts). Geoffrey Harcourt (2003) identifies the idea that the whole is more than the sum of the parts as the first of three key characteristics of the Cambridge economic tradition initiated by Marshall and absolutely central to Keynes's revolution in approach.

\section{Direct effects and indirect effects}

Now, if the whole is more than the sum of the parts we can never understand completely a given part of reality, since by studying a given part we are always missing its relationships to the whole. Therefore, Marshall's (1923) motto for his Industry and Trade, which appears also in Appendix C of Marshall's Principles of Economics (Marshall, 1920, p. 641), is 'the Many in the One, the One in the Many', which signals the presence of many different influences in a given aspect of reality, which is however one unified whole.

A problem that is raised by the presence of interconnectedness in a whole is how can any type of analysis proceed, since we are always limited to the study of parts of reality and can never grasp the whole as a whole - wholes 'qua wholes', to use John Maynard Keynes' (1973, p. 277) famous expression, on which see Tony Lawson (2003). In his Industry and Trade, Marshall formulates the problem of interconnectedness as he sees it:

It was not till the seventeenth century that the physical sciences appreciated the full importance of the fact that when several causes act together and mutually affect one another, then each cause produces two classes of effects; those which are direct, and those which result indirectly from the influences exerted by it on other causes: for indeed these direct and indirect effects are apt to become so intricately interwoven that they can by no means be disentangled. (Marshall, 1923 [1919], p. 677)

Marshall, however, provides the following solution to the problem, which will lead to Marshall's partial equilibrium analysis:

But a way out of the difficulty was found, chiefly under the guidance of Leibnitz and Newton. An epoch-making process of reasoning showed that, though the indirect effects might grow cumulatively, and ere long become considerable, yet at first they would be very small indeed relatively to the direct effects. Hence it was concluded that a study of the tendency to change, resulting from each several disturbing cause, might be made the starting point for a broad study of the influences of several causes acting together. (Marshall 1923 [1919], p. 677-8)

This separation between direct effects and indirect effects will be the cornerstone of Marshall's partial equilibrium (or particular equilibrium) analysis, where we can analyse the direct effects of a change in a shorter period of time, knowing however that in a longer period of time the indirect effects will manifest themselves. And Marshall sees this methodology as being grounded on Leibniz and Newton.

The reliance on a Newtonian methodology is not unrelated to Marshall's mathematical training in Cambridge. Mathematics in Cambridge was characterised by a Newtonian approach, where the emphasis was on geometrical and mechanical problems, rather than on symbolic algebra. The Cambridge mathematical environment did not maintain a strictly Newtonian approach to mathematics after 1815 . But some 


\section{Page 6 of $20 \quad$ N. O. Martins}

elements of a Newtonian approach, such as the emphasis on geometry and a concern with practical (and mechanical) problems, survived in the Cambridge Mathematical Tripos undertaken by Marshall (see Cook, 2009).

In fact, a Newtonian approach to mathematics can be characterised as one where mathematics is grounded on geometry and concerned with practical (and mechanical) problems. This approach contrasts with the Cartesian approach to mathematics, which was dominant in the European continent (and increasingly dominant in Cambridge during Marshall's life), where mathematics is grounded on algebra and not necessarily concerned with practical problems. The latter is actually Leibniz's own methodology; hence the differences between Newton's geometrical approach and Leibniz's algebraic approach to differential calculus (see Atiyah, 2005, pp. 654-7; Guicciardini, 2009).

But a common aspect of the methodologies of Newton and Leibniz is the principle of continuity. The principle of continuity appears also in the unpublished manuscripts of Henry Sidgwick (Add Msc 96/2) — who Marshall called his 'spiritual father and mother' - where Sidgwick discusses the law of continuity of Leibniz. Marshall's reliance on Newton and Leibniz and the issue of continuity constitutes a general methodology, which provides a justification for the separation between direct effects and indirect effects:

If $\mathrm{A}$ is a state of things influenced by conditions $\mathrm{B}$ and $\mathrm{C}$; while $\mathrm{B}$ and $\mathrm{C}$ are so connected that a change in $\mathrm{B}$ sets up simultaneous tendencies to change in both $\mathrm{A}$ and $\mathrm{C}$; then the changes produced in $\mathrm{A}$ and in $\mathrm{C}$ will at first be very small, though they may increase continually and cumulatively. Now since the immediate effect which a considerable change in B exerts on $\mathrm{C}$ would be very small; the immediate effect which the change B exerts on A indirectly through a very small change made by it in $C$, must be a very small part of a very small thing (...) and be negligible provisionally. But yet its accumulated effects may need consideration in special cases. (Marshall, 1923 [1919], p. 678)

The separation between direct effects and indirect effects will thus be Marshall's basis for economic analysis. Economic analysis can then focus on the direct effects of a change, which may be mathematically represented, using the differential calculus of Newton and Leibniz, as a first derivative. The indirect effects, which may be mathematically represented, using the differential calculus of Newton and Leibniz, as second derivatives, have a smaller effect that only shows itself cumulatively as time goes by. So if we assume a period of time short enough so that only direct effects will take place, we can thus undertake partial (or particular) equilibrium analysis, which is the analysis of a given part of reality, while leaving indirect effects aside. Hence, in the short period we can look at a particular market using supply-and-demand curves, while assuming everything else (i.e. the 'indirect effects') to be negligible or constant - the pound of ceteris paribus.

\section{Sraffa's critique of partial equilibrium analysis}

Sraffa was critical of Marshall's use of supply-and-demand functions while assuming everything else constant. Sraffa's critique was famously published in his 1925 and 1926 articles. It is important to note that Sraffa's critique is directed at the whole Marshallian tradition, which had been systematised by Arthur Cecil Pigou. This also means that Sraffa may also be reading much of Marshall through Pigou. In fact, 
to criticise Marshall himself would be a more difficult endeavour, since Marshall's position is not always as clear and one-sided as it is sometimes depicted by the Marshallians.

But the debate concerning Sraffa's $(1925,1926)$ critique of Marshall is based on Sraffa's articles that were written before 1927, i.e. before the crucial turning point in Sraffa's thinking identified by Garegnani (2005). When Sraffa's critique is revisited in the symposium that took place in 1930 in the Economic fournal (Robertson et al., 1930), it is Dennis Robertson and Gerald Shove who defend the Marshallian tradition. In this exchange we find already a change of tone in Sraffa's critique, which becomes much sharper than in the previous articles of 1925 and 1926, as Annalisa Rosselli (2005) notes.

The change of tone may also be due to the fact that Sraffa was already a more established scholar after the 1925 and 1926 articles. But this change of tone is certainly not unrelated to Sraffa's 'rediscovery of the position of the "old Classical economists", beyond the Marshallian interpretation he had hitherto followed' (Garegnani, 2005, pp. 453-4). A sharper tone is also adopted by Sraffa (1932), when criticising Friedrich Hayek's theory of capital. This supports the claim that Sraffa's critique of all perspectives informed by marginalism, from neoclassical economics to Austrian economics, was undertaken in a sharper tone after 1927, the time when he comes to see classical political economy in a radically different light, in which no reconciliation with marginalism was possible.

But there is a crucial methodological point for Sraffa's critique of Marshall's method, which becomes clear in Sraffa's unpublished manuscripts. As Maria Cristina Marcuzzo and Annalisa Rosselli (2011, p. 10) note, Sraffa writes in the unpublished papers, concerning the 'the nature of the curves of the marginal analysis' that:

This is nothing less than a declaration of faith in universal determinism, for nothing less can support the belief in the actual existence of a prescribed path which must inevitably be followed, whether by the consumer or by the producer, such as is described by the demand-and supply-curves: for no observation, however minute, of the existing situation (in our case, of the existing methods of production) can bring out the path along which they must move in any given circumstances. (Sraffa, D3/12/46/52)

So, for Sraffa only, 'faith in universal determinism' can justify the belief that changes in the (demand or supply) curve will inevitably lead to the partial equilibrium prices as assumed by Marshall. Sraffa writes:

The fundamental fallacies in Marshall are:

The principle of substitution

The principle of continuity, in its two applications:

1) To time 'long and short periods'

2) To matter, 'consideration of the margins as infinitesimals'

The metaphysics of utility-sacrifice

His one great contribution is the intelligent application of Leibnitz and Newton analysis to economics (Ind. and Trade, p. 677-8 text and note). (Sraffa, D3/12/11/11, original emphasis)

In this note from November 1927 (i.e. written during the 'turning point' identified by Garegnani, 2005), we can see that Sraffa was aware of Marshall's methodological justification of partial equilibrium analysis given in Industry and Trade and the principle of continuity. In fact, Sraffa recognises that the use of the method of 


\section{Page 8 of $20 \quad$ N. O. Martins}

Leibniz and Newton is perhaps the greatest contribution of Marshall. However, Sraffa considers the principle of continuity as one of the great failings of Marshall, both in its application to time (and in the division between short and long periods) and in its application to infinitesimals, in which Marshall draws upon Newton and Leibniz.

There are various reasons for Sraffa's scepticism concerning the use of a Newtonian methodology. Sraffa (D3/12/42/9, first proposition) writes, in a note written in Italian, that Marshall's adoption of Newton's method is erroneous, noting that Newton did not have the difficulty of having to assume an heterogeneous aggregate as being constant. Also, Sraffa points out how in the twentieth century Marshall could not rely on Newtonian mechanics unproblematically, referring to Erwin Schrödinger in this connection.

In fact, if Marshall's partial equilibrium analysis was based on Newtonian mechanics, this also meant that it was based on a conception of natural science that was being challenged by quantum physics, in which Sraffa was interested at the time. Heinz Kurz and Neri Salvadori (2005, p. 84) argue that 'Sraffa ... showed a particular interest in quantum theory, championed by physicists such as Werner Heisenberg, Erwin Schrödinger and Paul Dirac.'They continue:

Sraffa read and annotated P. W. Bridgman's The Logic of Modern Physics (Bridgman, 1927) and referred to it in his papers. Quantum theory can be said to have brought about the greatest revision of thinking about the nature of the physical world since the days of Isaac Newton and constituted a revolution in our understanding of physical processes and beyond. What was to be learned from it in economics and did this have implications for the received marginalist doctrine? As several notes and manuscripts written over a long period of time show, Sraffa was convinced that it was especially the idea of continuity that had been undermined by recent developments. This idea had also made its way into economics, in particular in terms of the assumption of the contiguity of any pair of 'adjacent' methods of production in the production function of a commodity. Alfred Marshall had expressed the idea of continuity in the motto of his Principles of Economics as 'Natura non facit saltum'. To Sraffa, demand and supply curves involved a false analogy with Newtonian mechanics. (Kurz and Salvadori, 2005, p. 85)

Sraffa's reading of quantum theory may have influenced his scepticism concerning the application of Newtonian mechanics. But Sraffa does not argue that economics should simply follow the 'latest trend' in physics and criticise Newtonian analogies only because it was challenged within physics by Schrödinger's quantum theory. In fact, Sraffa also writes, comparing Marshall and Hobson on the one hand, and Newton and Schrodinger on the other:

What Newton had proved about physics was of course quite irrelevant to Economics, and Marshall must have been short of good arguments to use such an unfair trick. At the present day this would not be possible, as witness \{Schrodinger\}. It should be added that $\{$ Schrodinger\} cannot be used to demolish \{marginal theory\} any more than Newton could prop it - except to the extent that it is in fact supported by the prestige appeal - which may well be large. (Sraffa, D3/12/42/10, sixth proposition)

In any case, we can see that not only Sraffa found Marshall's use of Newton's method deeply problematic, as he was also very aware of the methodological justification that Marshall had provided for it, grounded on Newton's principle of continuity. Sraffa is aware of Marshall's methodology and criticises the very foundations of it. To understand this we must now address Sraffa's discussion of the principle of continuity in more detail. 


\section{Sraffa's critique of the principle of continuity}

Sraffa (D3/12/11/40) writes that the period of time is just the interval between cause and effect - it is a definite not an arbitrary length - while adding that time is thus discontinuous. In yet another note, Sraffa (D3/12/11/62) explains that time is an objective duration, not an arbitrary segment of the continuous. The following note, written by Sraffa on 20 August 1963, further clarifies his own conception of continuity:

It is possible for a point to move continuously on a line. It is possible for a line to move continuously on a surface. But, is it possible for a point to move continuously on a surface? [Obviously, continuous motion means 'covering part of surface'] then No. Marginalism is based on experiments of the first type (linear) and then illegitimately extended to second (surface $=n$ 'factors'). For instance, indifference curves are traced by continuous imaginary experiments with two goods: but could an indifference curve be drawn between 3 goods (not to speak of more). (Sraffa, D3/12/42/10, original emphasis)

This notion of continuity is one in which continuity entails a connection between different points or lines, where the connection implies covering all the relevant dimensions. For example, when a point, which has no dimension, moves over a (unidimensional) line it covers all the dimensions of the line, because there is only one dimension to be covered; thus there is continuity in this movement in Sraffa's sense, because all the dimensions at play (in this case one dimension) are covered-curiously, this definition of continuity closely follows Newton's own definition of a line, which Newton takes to be the result of the continuous movement of a point, which creates the line through its continuous movement (see Guicciardini, 2009, for a discussion).

Likewise, when a line moves over a two-dimensional surface, it covers all the dimensions of the two-dimensional surface. However, when a point moves over a two-dimensional surface, the line created by this movement (or along which this movement takes place, if we take the dimension to pre-exist the movement rather than being created by the movement, as Newton would argue) is insufficient to cover the two-dimensional surface. Quite the contrary, the unidimensional line that results from this movement occupies in fact no space in the two-dimensional surface. Thus, there is no continuity in the sense Sraffa is using the word, i.e. in the sense of occupying or covering all the existing dimensions.

Within this conception of continuity, Sraffa then argues, in the note reproduced above, that an indifference curve cannot be drawn for three goods or more, but only for two goods. It is, however, difficult to see how this necessarily follows from Sraffa's notion of continuity. In fact, six days after writing the note on continuity above, and its implications for drawing indifference curves, Sraffa adds the following on 26 August 1963:

The above goes too far, perhaps. It is probably possible mathematically to construct an indifference curve for ' $n$ ' factors. Yet the substance of the argument holds. (Sraffa, D3/12/42/10)

The substance of the argument is that we cannot analyse only two variables, as if the others were constant, since even if we assume other variables to remain constant, there is still a different proportion between the variable that changed and the others that did not. So we must take all relevant variables into account. Sraffa (D3/12/42/10) draws the implications of this issue for the marginalist framework, noting how 'different proportions, between factors, when one factor changes and others remain constant makes marginal product meaningless'. Sraffa also draws the implications of this critique for the neoclassical framework of Marshall and Pigou: 


\section{Page 10 of $20 \quad$ N. O. Martins}

The idea is that the process of change can be reduced to a continuous process ... \{Marshall\} is constantly on the defensive against objections to continuity based on facts [example Pigou]. This is not the basis on which this is based. That can be taken for granted in detail, wherever it is possible. It is against the logical possibility of the type of continuity assumed. That type is only possible with two factors. (Sraffa, D3/12/42/12, original emphasis)

Effectively, if there were more than two factors (or variables), one would have to take all the variables into consideration, since a change in one of them, even when others remain constant, changes the proportions between them. Thus, Sraffa concludes that Marshall's method, and the type of continuity it assumes, is only possible when the two variables being analysed are in fact the only two variables that exist, but not when there are other variables being (wrongly) ignored, and assumed to be constant, as Marshall assumes.

The role that continuity plays in this regard can perhaps be best understood when Sraffa addresses the role of time. While the example provided above is a geometrical one, in which Sraffa addresses the issue of continuity in terms of space, in another note Sraffa (D3/12/13/1) addresses the issue of continuity while dealing with time. Sraffa suggests that we study not a continuous movement through time (as Marshall does), but rather look at an instantaneous photograph of the economy, i.e. at how the economy appears in a given moment of time:

This notion of time is important: it really substitutes «instantaneous photographs» as opposed to ordinary time. It is only a part of ordinary time, it has only some of its connotations: it includes events, also different events, but not change of events. It enables us to compare two simultaneous, but not instantaneous, events, just as if they were "things".

It is, in effect, equivalent to the physicists' $d t$ (as understood by Russell (Outline of Phil., p. 122)) - a time in which effects follow causes, but so closely that there is no room either for dispersion or for entering of foreign influences: $d t$ does this by differentiation (making time so short as actually to leave no room for change in circumstances: the cause and effect are perfectly contiguous - nothing happens in between) — our «time» does this by «assuming» away all changes (i.e. "ceteris paribus"? no: by positing the problem in the form of finding the conditions of repetition indefinitely, or even once).

This conception of time enables us to take into account, not only stocks (as the instantaneous view does) but also steady or cyclical flows (which that does not), while still using the geometrical model. (Sraffa, D3/12/13/1(3), original emphasis)

Here we find the essence of Sraffa's methodology: rather than assuming away all changes as Marshall does in the pound of ceteris paribus, we should rather describe the conditions of repetition (or reproduction) of the economic process. Marshall's method consists of making the period of time short enough so that nothing happens between a given cause and its effect, and so there is continuity between them (this is, of course, Newton's method of infinitesimal calculus, in which the time interval is infinitesimally small). To achieve this only two variables are considered at each time and a causal line can be drawn between those two contiguous events while forgetting all the other dimensions. But Sraffa writes, criticising this conception:

We are not bound to have only two variables at a time, we can consider them all simultaneously. (Sraffa, D3/12/42/35, original emphasis)

And the method for analysing all variables simultaneously consists of the analysis of the conditions of repetition (or reproduction) of the economic process in its totality, which is what Sraffa (1960) provides in his Production of Commodities by Means of Commodities. Sraffa's method is an analysis of what is presupposed in this continuous 
repetition (or reproduction) of a multidimensional economic process, while taking into account all the relevant variables simultaneously.

This is why no assumptions are made concerning returns to scale in Sraffa's (1960) book. For as Sraffa $(1960$, p. v) writes, he does not consider any changes in output and so no question arises as to whether we are in the presence of constant returns to scale or of any other returns to scale (increasing or decreasing). Sraffa does, however, consider changes in distribution, showing the inconsistency of the marginalist analysis of distribution. In fact Sraffa also discusses this issue in his unpublished manuscripts and argues that by following the principle of continuity, we would be led to different results from the ones reached by Marshall:

But if the number of the means of production is more than two, most of the resulting positions, however close to the original, actual, one, will be impossible. For, in correspondence, with a rise (or fall) however small of $r$, the most profitable position will in general involve a change (some up and some down) in many or all the quantities of means of production. And there is no ground for supposing that the change in 'others' is negligible compared with the change in the chosen one.

Thus, as a result of assuming perfect continuity, we get in general as a result discontinuity or rather: even though all quantities may move continuously (i.e. go through all the intermediate positions) it will never be possible to change one, however small the increment, while keeping the others constant. (Sraffa, D3/12/42)

So even if we admit continuity, for the sake of argument, the existence of more than two variables, and the interconnections between them, brings in discontinuity. Interestingly, both Marshall's and Sraffa's methods can be seen as responses to the problem of interconnectedness. Marshall's solution is to take the interval of time to be so short that only two events (the cause and the effect) occur and can thus be analysed in isolation, as contiguous events. Sraffa's method, on the other hand, is not to isolate a given part of the whole, but rather to study the conditions for the permanent reproduction of the whole, which are elaborated in the Production of Commodities.

\section{Sraffa and the critique of marginalism}

In Production of Commodities, Sraffa considers all the variables that are essential to formulate the overall structure of the economic system. Sraffa writes the following in the beginning of Production of Commodities:

It is ... a peculiar feature of the set of propositions now published that, although they do not enter into any discussion of the marginal theory of value and distribution, they have nevertheless been designed to serve as the basis for a critique of that theory. (Sraffa, 1960, p. vi)

Production of Commodities is in fact subtitled as being a 'Prelude to a Critique of Economic Theory'. This means that it is not a critique, but contains only the basic elements for others to undertake such a critique. Production of Commodities provides a basic framework, which contains not only the key elements for a critique of marginalism but also the key elements to explain the economic process of production (and reproduction). As Garegnani (1998) argues, it provides a 'core', at the level of 'pure theory', to use Luigi Pasinetti's (2005) expression, which must be supplemented by further 'institutional analysis' or, as Garegnani (1998, p. 419) writes, by 'what Marshall used to call "specific experience" (1920, p. 637)'-although, at least after chapter 1, the book is already presupposing a capitalist economy. 


\section{Page 12 of 20 N. O. Martins}

Such an institutional analysis would require some understanding of human behaviour. On this topic we find Sraffa defending a view that is again opposed to neoclassical economics. While the latter came to portray the human agent as an optimiser responding to subjective preferences (unlike Marshall himself, who had a much more realist conception of the human agent), Sraffa stresses that human beings are creatures of habit:

man learns from experience, or at any rate is changed by it, forms and transforms habits, etc (This is recognized by Marshall ... but he does not draw the inevitable conclusion that what he draws are historical, not equilibrium, diagrams). (Sraffa, D3/12/42/11)

One may wonder whether the emphasis on equilibrium rather than on history comes from Marshall himself, as Sraffa seems to imply, or from Marshall's followers such as Pigou, as Groenewegen (1982, pp. 13-14) argues. Probably Sraffa is reading Marshall too much through Pigou here, as in other cases. As Neil Hart (2004, p. 189) writes, 'A. C. Pigou and his followers set about the task of refining Marshall's equilibrium theory in such a way that history became divorced from economic analysis.'

Nevertheless, Sraffa is certainly right to note that Marshall had a realist conception of the human agent and that he did not develop the implications of the latter for his economic diagrams. Sraffa draws the implication of his conception of the human agent, as influenced by the behaviour of others, for Marshall's approach:

Besides, for \{supply and demand\} curves, external \{circumstances\} include the behaviour of our individuals: for the action of an individual is not independent of others, and individual demand (or supply) curves cannot be aggregated into a collective curve (as is well-known for supply curves, \{and\} as Pigou as acknowledged at least for some cases of demand). (Sraffa, $\mathrm{D} 3 / 12 / 42 / 11)$

We must, however, bear in mind that Sraffa's point is not that marginalism does not provide the right conclusions at many instances, but rather that it does so through an inconsistent method. Sraffa writes:

The marginal method is an unwarranted extension of the commonsense proposition that an employer will not keep a workman if by sacking him he saves more from his wages than he loses in his product - or take one more man if he can gain thereby: the same of course applies to remit of any means of production. Where marginalism goes astray is in (falsely) assuming further, A) that it is a method (a route) for reaching the most economic position (i.e. equilibrium)-whereas it is at best (i.e. when practicable) a means of ascertaining whether one is there or not, and also if one is in the neighbourhood of getting precisely there (...) B) that it has general applicability, whereas in fact it only applies exceptionally (in cases where partial change is feasible, where there is independence, the whole is not affected). It must not be thought that in rejecting the marginal principle, one rejects this commonsense proposition. (Sraffa, D3/12/42/9)

The idea that 'the whole is not affected' is in fact related to the problem of interconnectedness. But a key difference between Marshall and Sraffa is that Sraffa does not consider all conceivable variables simultaneously, as Marshall thought one would have to. Marshall was led to a partial equilibrium analysis after realising that such a task would be impossible.

In earlier writings Sraffa discusses the problem of the selection of the variables to be included, while nevertheless addressing still the totality of the economic system. The strategy that Sraffa follows is to look at objective data. Thus, in a note dated October 1929, Sraffa writes: 
Clearly, we must reduce all the data to things that actually happen, excluding inexistent possibilities. Only such things are measurable, and can enter the theory as "unknowns» or "constants»; and in reality, only really happening things can be real causes and determine effects. (Sraffa, D3/12/13/1(2), original emphasis)

Here we find a summary of Sraffa's objectivist approach, where the variables to be considered are not all the conceivable variables, objective and subjective (as in Marshall's approach), but only objective facts, in which all other factors will become manifest. Sraffa distinguishes between three groups of quantities:

1) Those which cannot possibly be measured ... e.g. \{marginal $\}$ utility and sacrifice

2) ... quantities which can be, and in fact are, statistically measured. These quantities have an objective, independent existence at every or some instant of the natural (i.e. not interfered with by the experiments) process of production and distribution ... such are quantities of various materials used or produced, of lands, quantities of labour (?), lengths of periods (?), etc. These are the only quantities which must enter as constants in economic theory, i.e., which can be assumed to be "known" or "given». (The "extensive» theory of rent, and the labour theory of value only assume this kind of knowledge).

3) Finally, there is the class of quantities which form the basis of Marshall's theory (or, rather, of Pareto's), such as demand and supply curves, marginal productivities (i.e. rate of growth of total), indifference curves, etc. Here the constant quantities have no names - they are the parameters of curves ... they are alternatives, only one of which can exist in any one moment, not during the recurrent steady state process of production or consumption. (Sraffa, D3/12/13/2, original emphasis)

Sraffa grounds his theory on the second group of quantities, i.e. those that can be statistically measured and have an objective and independent existence, contrarily to Marshall, who adopts the third group of quantities as the basis for his theory. Sraffa (D3/12/42) argues that Marshall's supply-and-demand curves do not exist (nor their parameters, which are not objective constants) and are a false analogy with mechanics, using mechanical concepts such as 'elasticity'.

Sraffa's critique of marginalism extends not just to Marshall's neoclassical approach, but also to other forms of marginalism, such as Austrian economics. Thus, in the unpublished paper 'Margins and Margins', Sraffa notes that the margin does not exist and that although Bortkiewicz criticises Eugene Böhm-Bawerk for the use of non-existent counterfactuals, Bortkiewicz does not realise that the work of BöhmBawerk is a particular case of marginalism, and indeed Sraffa notes that Bortkiewicz himself accepts marginalism. The marginalist system is best systematised, according to Sraffa (D3/2/46/43), in the work of 'Wicksteed, the most consistent of marginalists' —on which see Wicksteed (1910) - to whom Sraffa also refers in the preface of Production of Commodities in order to distinguish marginalist analysis from the study of the differential rent.

The comments made above also clarify why Sraffa chooses the theory of production for his critique of marginalism. Sraffa (D3/12/42/9) notes that the right camp to attack marginalism is through the theory of production, not through the theory of utility. Sraffa writes:

while with utility 'the consumer is always right'-there is no other, independent, check, with production output can be measured independently, and can be found not to be so. (Sraffa, D3/12/42/9)

That is, in the theory of production we can compare the marginalist approach with an objective theory that shows its faults - a theory that Sraffa (1960) provides for such 


\section{Page 14 of 20 N. O. Martins}

a purpose, as he explicitly acknowledges in Production of Commodities-while in the theory of utility there is no objective basis for us to criticise marginalism.

A central aspect in this context, for Sraffa, concerns the achievement of an objective measure of costs, which can be used in the theory of production. In this context Sraffa criticises Marshall's notion of costs, which includes subjective elements. Marshall (1920) criticised Marx and Rodbertus for attributing all the value to labour. For Marshall, all human sacrifices or efforts, objective or subjective, are a source of value. This means that, for Marshall, it is not only the labour of the worker, but also the waiting from the capitalist who invests that constitutes the real cost. Thus, both labour and capital are entitled to part of the produce, depending on their relative contributions, since the waiting of the investor is also a sacrifice.

However, Sraffa (D3/12/11/59) writes that the notion of 'comparative cost' is unintelligible unless applied to 'physical cost and natural value', since the subjective aspects like 'sacrifices', mentioned by Marshall, are not comparable. Sraffa traces the evolution towards Marshall's approach, from the idea of 'cost', central to classical political economy, to the notion of 'sacrifice', essential to marginalism:

A. Smith \{and\} Ricardo \{and\} Marx indeed began to corrupt the old idea of cost-from food to labour. But their notion was still near enough to be in many cases equivalent. The decomposition went on at a terrible speed from 1820 to 1870: Senior's abstinence and Mill's mess of the whole thing. Cairnes brought it to the final stage «sacrifice» (did Marshall take it from Cairnes? See his Princ. Note p. 339, seems not). (Sraffa, D3/12/4/2)

This process of decomposition of Petty's conception of cost continued with the marginalist revolution, where, Sraffa (D3/12/4/2) writes, there was a shift 'from physical to psychical processes: Jevons, Menger, Walras'. Sraffa adds that:

This has meant the destruction of the classical \{political economy\} and the substitution of it, under the old name of the calculus of pleasure and pain (Hedonistic). (Sraffa, D3/12/4/2)

Classical political economy, for Sraffa, was a project outlined clearly in the writings of Petty, who had an objective conception of cost. This notion of cost must not include subjective elements. Thus, Sraffa (D3/12/42/39) notes that while for Hobson an expense for moral incentives is part of the necessary cost (which are both physical and moral), for Sraffa himself expenses for moral incentives are part of the surplus but not part of the costs, which are only physical. With Smith, Ricardo and Marx we find a development of classical political economy that leads to fruitful results, but contains a conception of cost that must be clarified.

\section{Metaphysics and methodology}

For Sraffa, an important reason why marginalism became successful was the need to find an alternative to Marx's development of classical political economy. Thus, Garegnani (2005, p. 457) writes that for Sraffa the "'immediate and simultaneous success" of the utility-based theory of value of Jevons, Menger and Walras' was a response to Marx, who showed how 'Classical P[olitical] E[economy], with its surplus to be arbitrarily divided leads straight to Socialism' (Sraffa, as cited in Garegnani, 2005, p. 489). But the interpretation of Marx in Britain is not an easy task, given its underlying metaphysics: 
This would be simply a translation of Marx into English, from the forms of Hegelian metaphysics to the forms of Hume's metaphysics (Keynes to-day, 26 XI. 27 has clearly outlined the divorce between English and Continental thought: the first descending from Descartes [and] Hobbes, the two original geniuses, to Locke, Hutcheson and ultimately Hume, the second from Spinoza (did he say that of S.?) from Kant to Hegel: they always remained foreign to one another). (Sraffa, D3/12/4/15)

For Sraffa, understanding the underlying metaphysics of a theory is essential for its proper use. Sraffa writes, concerning metaphysics, that:

By metaphysics here I mean, I suppose, the emotions that are associated with our terminology and frames (schemi mentali) - that is, what is absolutely necessary to make the theory living, capable of assimilation and at all intelligible. (Sraffa, D3/12/4/15)

Thus, for Sraffa every theory has an implicit metaphysics, which must be understood if we are to understand the theory. Sraffa concludes this discussion on metaphysics noting how:

Our metaphysics is in fact embodied in our technique; the danger lies in this, that when we have succeeded in thoroughly mastering a technique, we are very liable to be mastered by her. (Sraffa, D3/12/4/15)

The relation between methodology and metaphysics is thus essential to our understanding of the appropriateness of a given method. The emphasis that Sraffa puts on these methodological aspects cannot be stressed enough. As Annalisa Rosselli (2005, p. 405) notes, Sraffa writes, in a letter to Charles Parrish Blitch (dated 6 October 1975), that in economic theory the conclusions are sometimes less interesting than the route by which they are reached'. In fact, in his notes on Sidgwick, Sraffa copies the following passages:

Sidgwick, 59: "The importance of seeking the best definition» is far greater than the «importance of finding it». (Sraffa, D1/20/3, original emphasis)

That is, the methodological activity of seeking clear concepts and definitions is more important that the achievement of a definite theory. This note is next to another note where we see that Sraffa (D1/20/4) was looking precisely at the foundations of the theory of value, since the latter is a note on Sidgwick's discussion of the 'assumptions on which theory of value is generally based'.

The relation between metaphysics and the theory of value is also present in a note written in Italian, where Sraffa (D3/12/10/24) quotes a passage by Eduard Zeller on a fragment by Heraclitus that can be translated into English as 'all things are exchanged by fire, and fire for all things, as goods for gold and gold for goods':

But the importance of a comparison must not be exaggerated. The fire substance becomes something different (?), i.e. it transforms itself, as we will see, in water, land, meteor, but Heraclitus supposes (?) always that fire remains hidden in every derived substance, but not in act, as the Aristotelians (!) would say, but in power/potentiality. This comparison like all comparisons is not the expression of a material identity (?), since, if the substance-fire becomes an absolutely different one, like gold exchanges itself for meat, wood, wine or any other object, it is no more possible to talk of a universal substance. (Sraffa, D3/12/10/24, as translated in Kurz and Salvadori, 2010, p. 202)

This passage, with which Sraffa seems to disagree, leads him to consider a description of reality in terms of a universal substance. The idea of a universal substance, a hidden 


\section{Page 16 of 20 N. O. Martins}

substance behind material things, underpins the labour theory of value and certainly Marx's interpretation of it. But the idea of an underlying substance is essential not only to the theory of value, but also to our metaphysics.

For example, it is because a fluid and liquid substance can be seen as a whole that adapts itself to (or becomes individualised in) many forms that led Thales to claim that water was the primordial substance, the one from which many individual forms spring-Heraclitus' claim that fire is the universal substance is part of the subsequent discussion that took place after Thales. Thus, when Sraffa (D3/12/42/57) writes that Marshall assumes 'fluidity', 'liquid capital', we can see how the idea of fluidity is part of Marshall's conception that everything is interrelated and thus nothing is 'rigid' in the sense of being unaffected by changes somewhere in the overall system.

Stephen Pratten (1998) argues that Marshall's difficulties spring from the inconsistency between this underlying ontology presupposed by Marshall (which assumes a dynamic and interconnected reality, as is apparent when he points towards evolutionary biology) and the statical method he employs. This inconsistency is also related to the tension between history and equilibrium in Marshall—on which see Hart (2004), but see George Shackle (1965) for an alternative assessment according to which Marshall did succeed in creating unity between the conceptions of equilibrium and of evolution.

Marshall's approach, like Sraffa's, is an attempt to solve the problem of interconnectedness, a problem that was already central for pre-Socratic philosophers such as Thales and Heraclitus, amongst many others, and is also a key element of what may be termed as the Cambridge economic tradition, as Harcourt (2003) and Pasinetti (2005) argue. To address this problem, Marshall, following Newton, focuses on continuous movement and takes continuity to be an essential ontological (or metaphysical) constituent of reality. Remember that Newton argues that even a line is created by the continuous movement of a point.

Sraffa, in contrast, suggests that we look at an 'instantaneous photograph', in which the dynamic elements manifest themselves (just like the subjective elements will also manifest themselves in the objective elements that Sraffa addresses). To use a geometrical analogy, while Marshall, following Newton, would focus on the activity of drawing a line, Sraffa would look at what the line looks like at a given instant.

Sraffa's approach is not a new solution to the problem of interconnectedness and the metaphysics (or ontology) underlying this solution is essential to understand it. Heraclitus argued that every element is connected to another element, creating a permanent flow and interaction, which is constitutive of the world. Hence, for Heraclitus the primordial element is fire (as noted above when addressing Sraffa's discussion of Heraclitus' fragment), the constant transformation of entities. But this leaves us with the problem of how can we achieve knowledge of a reality that changes before we even have the chance of grasping it-a problem Marshall and Sraffa also faced.

Plato's solution to Heraclitus' problem was that what our knowledge grasps are timeless ideas, which materialise themselves in instants of the constant flow of matter. For Plato only the geometer can enter the academy Plato founded (hence the famous inscription at its entrance), because only the geometer can see the eternal (or timeless) forms already drawn (in the intelligible world), which materialise themselves in events (in the sensible world). The meaning of the world eternal can indeed be taken to be timelessness. As Ludwig Wittgenstein, who engaged in numerous philosophical 
discussions with Sraffa—on which see John Davis $(1988,2002)$ or Amartya Sen (2003) —wrote in his Tractatus:

If we take eternity to mean not infinite temporal duration but timelessness, then eternal life belongs to those who live in the present. (Wittgenstein, 1921, 6.4311)

This is an idea present in Boethius' book, The Consolation of Philosophy, and a central element of the Platonist tradition, which was once dominant in Cambridge (at least since the Cambridge Platonists) and influenced authors such as Whitehead, Moore and Keynes. We have, however, no evidence of the putative influence of Platonism on Sraffa.

But the underlying metaphysics at stake here (Platonist or other) is essential to understand Sraffa's theory, or any theory, as Sraffa himself argues. If we take eternity to mean an 'infinite temporal duration' (to use Wittgenstein's expression) and interpret Sraffa's theory in those terms, we will be led to interpret it as a theory of what will happen with enough (indefinite or infinite), time. As Harcourt (1981, p. 258) explains, this was 'Joan Robinson's interpretation of Sraffa's system', in which Sraffa's system was one in which we have 'already reached the end of Marshall's long period'. But as Harcourt also notes, Joan Robinson changed this interpretation and she writes later of Sraffa's system:

It does not represent a stationary state of an equilibrium position. It is simply the position that has been reached, 'today', as a result of accumulation of stocks and of technical knowledge over the past history. (Robinson, 1985, p. 164)

That is, Joan Robinson came to see Sraffa's system in terms of an 'instantaneous photograph' of the economy, taking into account what has been reached today, in a present that nevertheless reflects the effect of historical time.

This issue divides many prominent interpreters of Sraffa. For example, Alessandro Roncaglia, who provides a very clear explanation of Sraffa's discussion of 'instantaneous photographs', criticises Garegnani for interpreting Sraffa's system in terms of a long-period position, arguing that 'Sraffa's notion of production prices is a refinement of the classical (Petty, Smith, Ricardo) notion of natural prices expressing the conditions of reproduction of the economy at a moment in time' (Roncaglia, 2010, p. 174).

This is the interpretation we reach if we think not of an 'infinite temporal duration' but rather in terms of 'timelessness'. However, it is also true that for Sraffa each 'timeless' position (each 'instantaneous photograph') must contain the conditions of possibility for its permanent (or 'infinite' or 'eternal') repetition. Thus, it is also consistent with what Garegnani calls a long-period position, which need not mean a stationary position, but rather a normal position that contains the conditions of possibility for its permanent repetition. In fact, I had the opportunity to discuss this issue with the late Professor Garegnani, who replied to me the following:

As for the question of interpreting Sraffa in terms of 'long period analysis' (I now prefer to speak of 'normal prices' or 'normal position' to avoid the endless present confusions between 'long period' and 'stationarity'), I can understand your perplexities in relating that with the 'instantaneous photograph' of some Sraffa manuscripts. I believe however that the latter phrases take care essentially of quite a distinct question: Sraffa's early attempts to come to terms with his own unexpected results of a determination of prices with no (neoclassical) demand and supply functions - and later, may be, an attempt to present those results avoiding as much as possible the scandal of prices which can be determined without D\&S. I had, I believe, tried to argue this case in a paragraph (par. 13 I see) on an article of mine on Sraffa's "Turning Point". (Garegnani, excerpt from email sent to author on 16 May 2011) 


\section{Page 18 of $20 \quad$ N. O. Martins}

The article in case is Garegnani (2005), where a most convincing case is made concerning Sraffa's change of interpretation of the theory of value in 1927, which led to a different view of classical political economy, which contrasts with the Marshallian supply-and-demand analysis. The key to understand this problem lies in a topic that, according to Sraffa, is essential to interpret any theory: its underlying metaphysics or, as it is usually phrased today, its presupposed ontology. The ontology of classical political economy, as interpreted by Sraffa, presupposes the reproduction of a whole and so the proper method consists of studying the conditions for the reproduction of the whole, rather than the analysis of how supply and demand mutually determine the prices and quantities of a part of the whole.

\section{Concluding remarks}

Marshall argues that if the interval of time is sufficiently short, we can focus only on direct effects, assuming indirect effects to be negligible - the pound of ceteris paribus. However, Sraffa finds this methodology insufficient for several reasons. Sraffa argues that for everything else to remain constant when two variables interact, one being the cause of the other, we would have to assume the interval of time to be small enough so that nothing happens between them (between cause and effect). This occurs only in an infinitely small interval of time, as was presupposed in the analysis of Leibniz and Newton. But, as Sraffa argues, Newton's analysis is irrelevant to economics, since in economics we are not concerned only with infinitely small intervals of time.

Sraffa suggests that we solve this problem by focusing not on intervals of time, but rather on the overall economy at a given point in time. In so doing we should investigate what the conditions are for permanent repetition or reproduction of the economy at a given point in time, or 'instantaneous photograph'. This is the only way to take into account the interconnectedness of reality in a consistent way. But, for Sraffa, the elements to include in this 'instantaneous photograph' of the overall economic process are only objective entities, which can be objectively measured, and not subjective entities, such as preferences and utility.

A key methodological aspect at stake in Sraffa's critique and the subsequent development of an alternative framework is the critique of Marshall's principle of continuity. To understand this we must take into account what is the underlying metaphysics (or ontology) presupposed in Marshall's conception of continuity and also the underlying metaphysics (or ontology) presupposed in Sraffa's conception of continuity. As Sraffa writes, the underlying metaphysics of a theory is essential to understand it and this is also true, of course, of the interpretation of Sraffa's own theory.

\section{Bibliography}

Atiyah, M. 2005. Collected Works, vol. 6, Oxford, Oxford University Press

Cook, S. 2009. The Intellectual Foundations of Alfred Marshall's Economic Science: A Rounded Globe of Knowledge, Cambridge, UK, Cambridge University Press

Davis, J. 1988. Sraffa, Wittgenstein and neoclassical economics, Cambridge fournal of Economics, vol. 12, 29-36

Davis, J. 2002. Gramsci, Sraffa, Wittgenstein: philosophical linkages, European fournal of the History of Economic Thought, vol. 9, 384-401

Garegnani, P. 1998. Sraffa: the theoretical world of the 'old classical economists', European Fournal of the History of Economic Thought, vol. 5, 415-29 
Garegnani, P. 2005. On a turning point in Sraffa's theoretical and interpretative position in the late 1920s, European Fournal of the History of Economic Thought, vol. 12, 453-92

Groenewegen, P. 1982. History and political economy: Smith, Marx and Marshall, Australian Economic Papers, vol. 21, 1-17

Groenewegen, P. 2011. Review of 'Simon J. Cook, The Intellectual Foundations of Alfred Marshall's Economic Science. A Rounded Globe of Knowledge', Fournal of the History of Economic Thought, vol. 33, 137-9

Guicciardini, N. 2009. Isaac Newton on Mathematical Certainty and Method, Cambridge, MA, MIT Press

Harcourt, G. C. 1981. Marshall, Sraffa, and Keynes: incompatible bedfellows? Eastern Economic Fournal, vol. 7, 39-50. Reprinted pp. 250-64 in Kerr, P. 1982 (ed.), The Social Science Imperialists: Selected Essays of G.C. Harcourt, London, Routledge and Kegan Paul

Harcourt, G. C. 2003. The Cambridge economic tradition, pp. 44-51 in King, J. (ed.), The Elgar Companion to Post Keynesian Economics, Cheltenham, Edward Elgar

Hart, N. 2004. History and theory in Marshall, pp. 179-96 in Aspromourgos, T. and Lodewijks, J. (eds), History and Political Economy. Essays in Honour of P. D. Groenervegen, London, Routledge

Jevons, W. S. 1888 [1871]. Theory of Political Economy, London, Macmillan

Keynes, J. M. 1973 [1921]. The Collected Writings of fohn Maynard Keynes, vol.VIII: A Treatise on Probability, London, Royal Economic Society

Kurz, H. and Salvadori, N. 2005. Representing the production and circulation of commodities in material terms: on Sraffa's objectivism, Review of Political Economy, vol. 17, 69-97

Kurz, H. and Salvadori, N. 2010. Sraffa and the labour theory of value, pp. 189-215 in Vint, J., Metcalfe, S. S., Kurz, H., Salvadori, N. and Samuelson, P. (eds), Economic Theory and Economic Thought, London, Routledge

Lawson, T. 2003. Reorienting Economics, London, Routledge

Marcuzzo, M. C. and Rosselli, A. 2011. Sraffa and his arguments against 'marginism', Cambridge Fournal of Economics, vol. 35, 219-31

Marshall, A. 1920 [1890]. Principles of Economics, London, Macmillan

Marshall, A. 1923 [1919]. Industry and Trade, London, Macmillan

Marx, K. 1999 [1867]. Capital, Oxford, Oxford University Press

Meek, R. 1961. Mr. Sraffa's rehabilitation of classical economics, Scottish fournal of Political Economy, vol. 8, 119-36

Pasinetti, L. L. 2005. The Cambridge school of Keynesian economics, Cambridge fournal of Economics, vol. 29, 837-48

Pratten, S. 1998. Marshall on tendencies, equilibrium and the statical method, History of Political Economy, vol. 30, 121-63

Robertson, D. H., Sraffa, P. and Shove, G. F. 1930. Increasing returns and the representative firm, Economic Fournal, vol. 40, 79-116

Robinson, J. 1985. The theory of normal prices and the reconstruction of economic theory, pp. 157-65 in Feiwel, G. (ed.), Issues in Contemporary Macroeconomics and Distribution, Albany, New York Press

Roncaglia, A. 2010. Some notes on the notion of production prices, pp. 174-88 in Vint, J., Metcalfe, S. S., Kurz, H., Salvadori, N. and Samuelson, P. (eds), Economic Theory and Economic Thought, London, Routledge

Rosselli, A. 2005. Sraffa and the Marshallian tradition, European fournal of the History of Economic Thought, vol. 12, 403-23

Russell, B. 1945. A History of Western Philosophy, New York, Simon and Schuster

Sen, A. K. 2003. Sraffa, Wittgenstein, and Gramsci, fournal of Economic Literature, vol. 41, 1240-55

Shackle, G. 1965. A Scheme of Economic Theory, Cambridge, UK, Cambridge University Press

Shove, G. 1942. The place of Marshall's principles in the development of economic theory, Economic fournal, vol. 52, 294-329

Sraffa, P. 1925. Sulle relazioni fra costo e quantita prodotta, Annali di Economia, vol. 2, 277-328

Sraffa, P. 1926. The laws of returns under competitive conditions, Economic fournal, vol. 36, 535-50

Sraffa, P. 1932. Dr. Hayek on money and capital, Economic fournal, vol. 42, 42-53 


\section{Page 20 of $20 \quad$ N. O. Martins}

Sraffa, P. 1960. Production of Commodities by Means of Commodities: Prelude to a Critique of Economic Theory, Cambridge, UK, Cambridge University Press

Veblen, T. 1900. The preconceptions of economic science: III, Quarterly fournal of Economics, vol. 14, 240-69

Wicksteed, P. 1910. The Common Sense of Political Economy: Including a Study of the Human Basis of Economic Law, London, Macmillan

Wittgenstein, L. 1961 [1921]. Tractatus Logico-Philosophicus, trans. D. F. Pears and B. F. McGuiness, London, Routledge \& Kegan Paul 